\title{
Preface to special issue on relationship between continental tectonics and the seismic activities of China, research techniques and methods
}

\author{
Rui Gao
}

Published online: 27 April 2016

(C) The Author(s) 2016. This article is published with open access at Springerlink.com

As an essential element in studying Earth Sciences, plate tectonics provides the scientific basis for understanding movement and tectonic interactions among different plates and related tectonic consequences, i.e., natural hazards. The theory of plate tectonics was introduced to China in the early 1970s, about 10 years after this, scientific theory was firstly developed in the western world. Even though, after profound studies for several decades by Chinese and foreign geoscientists, it has been widely recognized that China is a tectonic collage built by successive amalgamations among different terranes (e.g., Meng and Zhang 1999).

Geoscientific studies indicate that the dominant amalgamation that constitutes the major frame of Chinese mainland first occurred between the North China block and the Qilian block during Early Paleozoic via closure of the Proto-Tethys Ocean. This process generated the currently widespread island arc assemblages within the Qilian orogenic belt, as well as accretionary prisms, ophiolites and high to ultrahigh-pressure metamorphic rocks (Xiao et al. 2009). The Qinling-Dabie-Sulu orogenic belt to the east of the Qilian orogenic belt is the prominent orogenic belt in China that resulted from closure of the branches of the Paleo-Tethys Ocean, including the Shangdan Ocean and, thereafter, the Mianlue Ocean, and the subsequent collision between North China block and South China block during Indosinian orogeny (e.g., Guo et al. 2012). It extends eastwest for about $2000 \mathrm{~km}$ (Li and Gerya 2009). Simultaneously with the closing Paleo-Tethys Ocean, divergent subduction occurred to the Songpan-Garze remnant ocean along the Kunlun suture zone to the north and the Jisha

R. Gao $(\bowtie)$

Institute of Geology, Chinese Academy of Geological Sciences, Beijing 100024, China

e-mail: ruigao126@126.com suture zone to the south, and thick Triassic flysch derived from adjacent orogenic belts migrated contemporaneously to the Songpan-Garze remnant ocean (e.g., Yin and Nie 1993; Liu et al. 2013). Meanwhile, owing to coeval subduction in the north and southwest, the Songpan-Garze remnant ocean experienced northeast-southwestward crustal shortening and, therefore, southeast-directed thrusting (e.g., Reid et al. 2005; Roger et al. 2011). Consequently, western margin of the Yangtze block, which was originally the passive margin prior to thrusting, was inverted to be the active margin (Guo et al. 2013, 2014, 2015a, b; Xu et al. 2016). Contemporaneously, the Longmenshan thrust belt adjacent to the western Sichuan basin was initiated as a result of resistance from the rigid basement of the Yangtze hinterland (Burchifel et al. 1995). A subsequent successive amalgamation of terranes that constitutes the Tibetan plateau, including the Songpan-Garze terrane, the Qiangtang terrane, and the Lhasa terrane, as well as the Indian plate, has been taking place, since Mesozoic, through Paleogene to Neogene, to present (e.g., Wang et al. 2008). The Tibetan plateau resulted from ongoing Indian-Eurasian collision has gained most concern, not only because of its high topography with double normal thickness crust, but also the influence of high topography to the climate changes in South Asia (Molnar et al. 1993), as well as the derived natural hazards within the interior of the plateau and along its margins. The Tibetan plateau is currently undergoing coeval uplift and tectonic extrusion along major strike-slip faults (Tapponnier et al. 2001). It has been taken as the primary active example of a continent-continent collisional orogen (e.g., Searle et al. 2011; Styron et al. 2015). In addition to the active tectonics taking place in the interior of Chinese mainland, forces from outside have exerted influence to the evolution of Chinese mainland, resulting in tectonic activities along major faults. The 
most famous example is the Tanlu fault zone, which was initiated during Indosinian orogeny (Xu et al. 1987; Zhu et al. 2009) but was reactivated during Cenozoic with a reorganization of the plate tectonics (Chen et al. 2006).

Thus, Chinese mainland is experiencing compressive forces through the interactions between the Eurasian plate and the Indian Plate to the west, and between the Pacific Plate and Eurasian plate to the east. As a result, several major seismic belts are developed, including the seismicity in the coastal area of South China, seismicity along the Taihang Mountain and the area adjacent to Beijing, Tianjin, and Tangshan, and seismicity in southwestern Tibet and eastern Tibet adjacent to the Sichuan Province, as well as the North-South seismic belt along the Helanshan-Liupanshan-Longmenshan. Chinese mainland occupies $7 \%$ of the world's land but has had $33 \%$ of major earthquakes of the world indicating a frequent earthquake sequence of China. Since the twentieth century, more than 800 earthquakes with magnitude over 6.0 have been reported. The most recent well known ones are the $1976 M_{\mathrm{S}} 7.8$ Tangshan earthquake, the $2001 M_{\mathrm{S}} 7.8$ Kunlun earthquake, and the $2008 M_{\mathrm{S}} 8.0$ Wenchuan earthquake, as well as the 2010 $M_{\mathrm{S}} 6.9$ Yushu earthquake.

Although Chinese mainland has frequent earthquakes, unfortunately, it is still in the empirical stage for the earthquake prediction. However, the factual and theoretical basis for studies in crustal structure and tectonics has gained much improvement in research methods and techniques, which is of great significance for preparation of natural hazards, like earthquakes. Seven papers collected in the special issue reflect the latest development and progresses in the studies of active tectonics in China. All the selected papers document the crustal structure of a specific area by using different methods. Xiong et al. and Huang et al. employed high-resolution seismic reflection profiles to image the crustal structure. Differently, Huang et al. concentrated on the structural interpretation of the deep process and the sub-horizontal Moho, while Xiong et al. focused mostly on the tectonic evolution of the Sichuan basin, since Archean based on the well-developed reflectors appearing from lower crust to the mantle. Additionally, Xiong et al. employed gravity anomaly as a data support to identify the variation in mechanical properties of the whole crust. Similarly, Xu et al. have concentrated on the studies of gravity anomaly of eastern Tibetan to identify the relationship between the regional tectonic activity and crustal structure. Different processing techniques of the gravity anomaly have quiet improved the interpretation resolution of the crustal structure. To the south of eastern Tibet, by discussing the crustal stress field, Xu et al. documented the crust-mantle structure beneath Yunnan Province. The authors suggested a vertically coherent pureshear deformation of the lithosphere, which indicates a coupled crust-mantle structure. To the South China block, Chen et al. have concentrated on the documentation of the crustal structure beneath the Xuefeng Mountain uplift belt by using a magnetotelluric study. With a combination of regional gravity and magnetic data, the results reveal the basement detachment and north-south ramp accompanied with the tectonic movement. Further, with an integrated data analysis including remote sensing and topographic surveys, seismic data from petroleum exploration, shallow seismic profiles, exploratory geological trenches on fault outcrops, and borehole data, Shao et al. re-localized the epicenter of 1119 AD Qian-Gorlos earthquake and pointed out the potential of the Gudian fault in triggering large earthquakes in the Songliao basin of Jilin Province. Hu et al. contributed one paper with documentation of the lithospheric elastic thickness over the Louisville Ridge and adjacent regions, the Hawaiian-Emperor Chain, by using bathymetry and altimetric gravity anomalies. The results indicate an increase of the lithospheric effective elastic thickness seaward as a result of the collision of the Pacific and Indo-Australia plates.

Overall, progress of techniques and methods in improving tectonic studies is undergoing concurrently. Emphasizing the tectonic analysis without employing new methods and/or new techniques will probably eventually end up getting sealed in studies. Thus, based on the understanding of previous tectonic studies, results from employment of a new method and technique will add new aspects to construction of tectonic evolution model and, therefore, provide an alternative preparation for future natural hazards.

Finally, I would like to acknowledge all the authors for their fruitful contributions. More specifically, I would give my special thanks to all the reviewers for their responsible and careful readings of the papers. Their evaluation, opinions, and suggestions for modification of reviewed papers do provide the authors an opportunity to emphasize the main lines of evidence in support of their hypotheses.

Open Access This article is distributed under the terms of the Creative Commons Attribution 4.0 International License (http://crea tivecommons.org/licenses/by/4.0/), which permits unrestricted use, distribution, and reproduction in any medium, provided you give appropriate credit to the original author(s) and the source, provide a link to the Creative Commons license, and indicate if changes were made.

\section{References}

Burchifel BC, Chen ZL, Liu YP, Royden LH (1995) Tectonics of the Longmen Shan and adjacent regions, central China. Int Geol Rev 37:661-735

Chen L, Zheng TY, Xu WW (2006) A thinned lithospheric image of the Tanlu Fault zone, eastern China: constructed from wave 
equation based receiver function migration. J Geophys Res 111:B09312. doi:10.1029/2005JB003974

Guo XY, Encarnacion J, Xu X, Deino A, Li ZW, Tian XB (2012) Collision and rotation of the South China block and their role in the formation and exhumation of ultrahigh pressure rocks in the Dabie Shan orogen. Terra Nova 24:339-350

Guo XY, Keller RG, Gao R, Xu X, Wang HY, Li WH (2013) Imaging the crustal structure beneath the eastern Tibetan Plateau and implications for the uplift of the Longmen Shan range. Earth Planet Sci Lett 379:72-80

Guo XY, Keller RG, Gao R, Xu X, Wang HY, Li WH (2014) Irregular western margin of the Yangtze block as a cause of variation in tectonic activity along the Longmen Shan fault zone, eastern Tibet. Int Geol Rev 56:473-480

Guo XY, Gao R, Xu X, Keller RG, Yin A, Xiong XS (2015a) Longriba fault zone in eastern Tibet: an important tectonic boundary marking the westernmost edge of the Yangtze block. Tectonics. doi:10.1002/2015TC003880

Guo XY, Gao R, Wang HY, Li WH, Keller RG, Xu X, Li HQ, Encarnacion J (2015b) Crustal architecture beneath the TibetOrdos transition zone, NE Tibet, and the implications for plateau expansion. Geophys Res Lett 42:10631-10639. doi:10.1002/ 2015GL066668

Li Z, Gerya TV (2009) Polyphase formation and exhumation of highto ultrahigh-pressure rocks in continental subduction zone: numerical modeling and application to the Sulu ultrahighpressure terrane in eastern China. J Geophys Res 114:B09406

Liu SG, Deng B, Jansa L, Wang GZ, Li XH, Wang CS, Liu S, Li ZW, Li JC, Sun W, Ran B (2013) Late Triassic thickening of the Songpan-Ganzi Triassic flysch at the edge of the northeastern Tibetan Plateau. Int Geol Rev 55:2008-2015

Meng QR, Zhang GW (1999) Timing of collision of the North and South China blocks: controversy and reconciliation. Geology 27:123-126

Molnar P, England P, Martinod J (1993) Mantle dynamics, uplift of the Tibetan Plateau, and the Indian monsoon. Rev Geophys 31:357-396

Reid AJ, Wilson CJL, Liu S (2005) Structural evidence for the Permo-Triassic evolution of the Yidun arc, eastern Tibetan Plateau. J Struct Geol 27:119-137

Roger F, Jolivet M, Cattin R, Malavieille J (2011) MesozoicCenozoic tectonothermal evolution of the eastern part of the
Tibetan Plateau (Songpan-Ganze, Longmen Shan area): Insights from thermochronological data and simple thermal modeling. In: Gloaguen R, Ratschbacher L (eds) Growth and collapse of the Tibetan Plateau: Geological Society, London, Special Publications, vol 353, pp. 9-25

Searle MP, Elliott JR, Phillips RJ, Chuang SL (2011) Crustallithospheric structure and continental extrusion of Tibet. J Geol Soc Lond 168:633-672

Styron R, Taylor M, Sundell K (2015) Accelerated extension of Tibet linked to the northward underthrusting of Indian crust. Nat Geosci 8:131-134

Tapponnier P, Xu ZQ, Roger F, Meyer B, Arnaud N, Wittlinger G, Yang JS (2001) Oblique stepwise rise and growth of the Tibetan Plateau. Science 294:1671-1677

Wang CS, Zhao XX, Liu ZF, Lippert PC, Graham SA, Coe RS, Yi HS, Zhu LD, Liu S, Li YL (2008) Constraints on the early uplift history of the Tibetan Plateau. PNAS 105:4987-4992

Xiao WJ, Windley BF, Yong Y, Yan Z, Yuan C, Liu CZ, Li JL (2009) Early Paleozoic to Devonian multiple-accretionary model for the Qilian Shan, NW China. J Asian Earth Sci 35:323-333

Xu JW, Zhu G, Tong WX, Cui KR, Liu Q (1987) Formation and evolution of the Tancheng-Lujiang wrench fault system: a major shear system to the northwest of the Pacific Ocean. Tectonophysics 134:273-310

Xu X, Keller GR, Gao R, Guo X, Zhu X (2016) Uplift of the Longmen Shan area in the eastern Tibetan Plateau: an integrated geophysical and geodynamic analysis. Int Geol Rev 58:14-31

Yin A, Nie S (1993) An indentation model for North and South China collision and the development of the Tanlu and Honam fault systems, eastern Asia. Tectonics 12:801-813

Zhao RX, Liou JG, Zhang RY, Li TF (2006) SHRIMP U-Pb zircon dating of the Rongcheng eclogite and associated periotite: new constraints for ultrahigh-pressure metamorphism of mantledrived mafic-ultramafic bodies from the Sulu terrane. In: Hacker BR, McClelland WC, Liou JG (eds) Ultrahigh-pressure Metamorphism: Deep Continental Subduction. GSA Spec Pap 403:115-125

Zhu G, Liu GS, Niu ML, Xie CL, Wang YS, Xiang BW (2009) Syncollisional transform faulting of the Tanlu fault zone, eastern China. Int J Earth Sci 98:135-155 